\title{
Health Care Workers and Standard Precautions: Perceptions and Determinants of Compliance in the Emergency and Trauma Triage of a Tertiary Care Hospital in South India
}

\author{
Sangini Punia, ${ }^{1}$ Suma Nair, ${ }^{2}$ and Ranjitha S. Shetty ${ }^{2}$ \\ ${ }^{1}$ Department of Anesthesiology, University of Iowa Hospitals and Clinics, Iowa City, IA 52246, USA \\ ${ }^{2}$ Department of Community Medicine, Kasturba Medical College, Manipal University, Manipal, Udupi, Karnataka 576 104, India \\ Correspondence should be addressed to Suma Nair; sumavimal@gmail.com
}

Received 18 July 2014; Accepted 14 September 2014; Published 29 October 2014

Academic Editor: Pierre Parneix

Copyright ( $\odot 2014$ Sangini Punia et al. This is an open access article distributed under the Creative Commons Attribution License, which permits unrestricted use, distribution, and reproduction in any medium, provided the original work is properly cited.

Background. Careful adherence to standard precautions can protect both health care workers (HCWs) and patients from infections. The present study identified the perceptions and compliance with the use of standard precautions and assessed the determinants of noncompliance among the HCWs in an emergency and trauma triage centre. Methods. A cross-sectional study using a semistructured questionnaire was carried out to collect the relevant information from the study participants. Results. A total of 162 HCWs were recruited into the study, who reported varying degrees of compliance with standard precautions. While most of them declared the use of hand rub (95\%) and gloves (77\%), reported use of protective eye gear and outer protective clothing was very low (22 and 28\%, resp.). Despite a perceived risk of exposure to blood-borne infections, $8 \%$ of the HCWs had not completed the hepatitis B vaccination schedule. About $17 \%$ reported at least one needle stick injury in the past year but only $5.6 \%$ received medical attention. Conclusion. Inadequate adherence to standard precautions among health care providers warrants new training and monitoring strategies. Establishment of an effective occupational health cell incorporating these elements including periodic surveillance could be the way forward.

\section{Introduction}

Standard precautions are the minimum infection prevention practices that apply to all patient care, irrespective of suspected or confirmed infection status of the patient, in any health care setting. These practices aim to both protect health care workers (HCWs) and prevent them from transmitting the infections to their patients. Standard precautions include hand hygiene, use of personal protective equipment (e.g., gloves, gowns, and masks), needle safety, and safe handling of potentially contaminated equipment or surfaces in the patient environment including respiratory hygiene (cough etiquette) and disposal of sharps, body fluids, and other clinical wastes properly [1-3].

Health care workers face the occupational risk of exposure to infection with blood-borne pathogen during the course of their routine work in the wards, intensive care units, emergency/trauma triage, and so forth. Worldwide, almost three million HCWs experience percutaneous exposure to blood-borne pathogens each year [4]. Despite infection control precautions and availability of hepatitis B vaccine, health care providers remain at risk of acquiring bloodborne infections [5]. Many exposures can be prevented by careful adherence to existing infection control precautions, immunization against hepatitis $\mathrm{B}$, and provision of personal protective equipment during the management of emergencies [6-8].

Despite the availability of detailed guidelines, the knowledge and compliance with standard precautions vary among HCWs and have been found to be inadequate in both developed and developing countries [9-11].

Though there are reports regarding the compliance with standard precautions among HCWs in various parts of India, there is a paucity of information about the same among HCWs functioning in the emergency department of the health care settings. In this context the present study 
TABLE 1: Compliance with standard precautions among the participants $(N=162)$.

\begin{tabular}{|c|c|c|c|c|c|}
\hline Study participants & $\begin{array}{c}\text { Use of hand rub } \\
n(\%)\end{array}$ & $\begin{array}{c}\text { Use of gloves } \\
n(\%)\end{array}$ & $\begin{array}{c}\text { Use of masks } \\
n(\%)\end{array}$ & $\begin{array}{c}\text { Use of eye gear } \\
n(\%)\end{array}$ & $\begin{array}{c}\text { Use of gowns } \\
n(\%)\end{array}$ \\
\hline $\begin{array}{l}\text { Doctors } \\
(N=109)\end{array}$ & $78(71.5)$ & $90(82.6)$ & $38(34.8)$ & $21(19.2)$ & $36(33.0)$ \\
\hline $\begin{array}{l}\text { Nurses } \\
(N=53)\end{array}$ & $43(81.1)$ & $48(90.6)$ & $36(67.9)$ & $15(28.3)$ & $10(18.8)$ \\
\hline $\begin{array}{l}\text { Total } \\
(N=162)\end{array}$ & $121(74.7)$ & $138(85.1)$ & $74(45.6)$ & $36(22.2)$ & $46(28.4)$ \\
\hline
\end{tabular}

was undertaken to identify the perceptions and compliance with the use of standard precautions as well as to assess the determinants of noncompliance among HCWs in the emergency and trauma triage centre of a tertiary care hospital in southern Karnataka, India.

\section{Methods}

A cross-sectional questionnaire based study was carried out after obtaining ethical clearance from the institutional ethics committee (IEC). Study participants were the HCWs in the emergency and trauma triage centre of the hospital that has an active infection control committee and is compliant with biomedical waste management guidelines as well as good clinical practice. Participants included staff nurses, junior residents (interns and postgraduate trainees), and senior residents with a postgraduate training from the departments of medicine, surgery, and orthopaedics and who were frequently posted to the emergency and trauma triage at the hospital for emergency patient care. The staff nurses and junior and senior residents are the immediate care givers in cases requiring emergent care at this centre.

Estimating the practice of standard precautions among HCWs to be $52 \%$ [12] with a relative precision of $15 \%$ at $95 \%$ level of confidence, the minimum required sample size was 158. The total population of HCWs in the emergency and trauma triage centre at this hospital is 410 . Accordingly a total of 162 participants were recruited using the population proportionate to size sampling technique. The participants were randomly recruited into the study, after obtaining a written informed consent. Confidentiality of the participants was maintained by giving them a coded identity.

A predesigned semistructured questionnaire was used to collect the relevant information. It was self-administered and included questions pertaining to compliance with the use of hand rub, personal protective gear, needle safety by HCWs during patient care, and perceptions of risk and barriers to compliance.

Data was collected over a period of two months, was tabulated and analysed using Statistical Package for Social Sciences (SPSS) version 15.0, and was presented in proportions.

\section{Results}

Of the 162 HCWs recruited into the study, 53 (32.7\%) were staff nurses and 109 (67.2\%) doctors. Of the doctors, junior residents comprising interns (52) and postgraduate trainees (45) represented more than half $(59.8 \%)$ and the rest $(7.4 \%)$ were senior residents.

Table 1 shows participants' compliance with standard precautions during patient care.

3.1. Hand Hygiene. Almost three-quarters (74.7\%) of the study participants declared using hand rub as a personal protective measure and the majority (95.0\%) claimed to use it after touching contaminated items. However, a little less than half $(49.4 \%)$ stated its consistent use between patient interactions. This practice was reported highest among staff nurses $(81.1 \%)$ and relatively less among junior residents $(30.9 \%)$. Overall reported rates of hand rub use were high following procedures such as insertion of catheters $(94.4 \%)$ and blood draws (85.7\%). Sixty-three percent of the HCWs professed to always use hand rub after removing gloves.

3.2. Use of Personal Protective Equipment (PPE). As per the reported data, use of gloves appeared to be considerable while drawing blood (81.0\%) and during instances when coming in contact with mucous membranes or nonintact skin of the patients $(88.3 \%)$.

About $45.6 \%$ of the participants admitted using face masks while suturing, another $53.1 \%$ while undertaking procedures like inserting a nasogastric tube, and 39.5\% during a lumbar puncture. When confronted with a situation in which the risk of fluid splash was high and the HIV status of the patient was unknown, eye protection and protective gowns were said to be used by only $36(22.2 \%)$ and $46(28.4 \%)$ study participants, respectively. However, in situations where patient's HIV status was known to be positive, almost 96 (59.2\%) participants stated the use of eye protection and gowns.

3.3. Needle Safety. Various unsafe practices reported by the HCWs with respect to using needles for patient care are depicted in Table 2. Effectively $59.3 \%$ of the respondents admitted to always recapping used needles, while another $30.0 \%$ reported the practice of disengaging needles manually from the syringe. Nearly $18 \%$ of the respondents confessed to not placing the used needles in designated sharps containers. Not surprisingly $17.2 \%$ of the HCWs reported a needle stick injury (NSI) at least once in the last twelve months.

3.4. Perception of Risk. More than $60 \%$ of health care workers considered themselves at high risk of getting exposed to 
TABLE 2: Hazardous needle practices among the participants $(N=162)$.

\begin{tabular}{|c|c|c|c|}
\hline Unsafe practices & $\begin{array}{c}\text { Doctors } \\
(N=109) \\
n(\%)\end{array}$ & $\begin{array}{c}\text { Nurses } \\
(N=53) \\
n(\%)\end{array}$ & $\begin{array}{c}\text { Total } \\
(N=162) \\
n(\%)\end{array}$ \\
\hline Recapping needles after use & $79(72.4)$ & $17(32.1)$ & $96(59.3)$ \\
\hline Bending or breaking needles by hand after use & $14(12.8)$ & $8(15.1)$ & $22(13.6)$ \\
\hline Manual removal of needles from syringes & $26(23.9)$ & $23(43.4)$ & $49(30.2)$ \\
\hline Improper disposal of the used needles & $25(22.9)$ & $4(7.5)$ & $29(17.9)$ \\
\hline
\end{tabular}

TABLE 3: Perception and practice among HCWs $(N=162)$.

\begin{tabular}{|c|c|c|c|}
\hline HCWs & $\begin{array}{c}\text { Perceived risk of HIV/HCV } \\
\text { infection } \\
n(\%)\end{array}$ & $\begin{array}{l}\text { NSIs in the last one year } \\
n(\%)\end{array}$ & $\begin{array}{c}\text { Received complete schedule } \\
\text { of hepatitis B vaccine } \\
n(\%)\end{array}$ \\
\hline $\begin{array}{l}\text { Doctors } \\
(N=109)\end{array}$ & $70(64.2)$ & $24(22.0)$ & 99 (90.8) \\
\hline $\begin{array}{l}\text { Nurses } \\
(N=53)\end{array}$ & $34(64.2)$ & $04(7.5)$ & $51(96.2)$ \\
\hline $\begin{array}{l}\text { Total } \\
(N=162)\end{array}$ & $104(64.2)$ & $28(17.2)$ & $150(92.6)$ \\
\hline
\end{tabular}

blood-borne infections (64.2\% for HIV and $61.7 \%$ for hepatitis $\mathrm{B}$ and hepatitis $\mathrm{C}$ infection). Despite this perception, 12 (7.4\%) respondents had not received the complete schedule of the hepatitis B vaccine. Of the $17.2 \%$ respondents who claimed to have sustained a NSI in the past, only $5.6 \%$ admitted to reporting it to the concerned authorities (Table 3 ).

3.5. Barriers to Compliance. The study participants expressed certain hindrances in complying with PPE when warranted (Figure 1). While lack of time appeared to be the most common reason, protective equipment not being readily available during an emergency situation also figured prominently as a deterring factor. Other less prominent reasons were the likelihood of offending patients and not knowing the correct method of using the equipment. Doctors seemed to be negatively influenced by their peers in not using PPE.

\section{Discussion}

The present study shows varying degrees of compliance with the different measures contained within standard precautions. The majority of the participants declared use of hand rub $(74.7 \%)$ following most procedures. Compliance with glove use was reported by $85.1 \%$ in our study which corroborates the findings of a study from Nigeria [13]. The reported use was high (90\%) when in contact with potentially infectious surfaces and this is in keeping with findings (97\%) from a developed country setting [14].

In spite of the perceived risk of getting exposed to bloodborne infections, in the present study $7.4 \%$ of the HCWs had not completed the hepatitis B vaccine schedule. This is, however, better than the findings from studies conducted in the northern part of India [12] and the United States [15] that report higher rate of incomplete hepatitis B vaccination $(23 \%$ and $25 \%$, resp.).

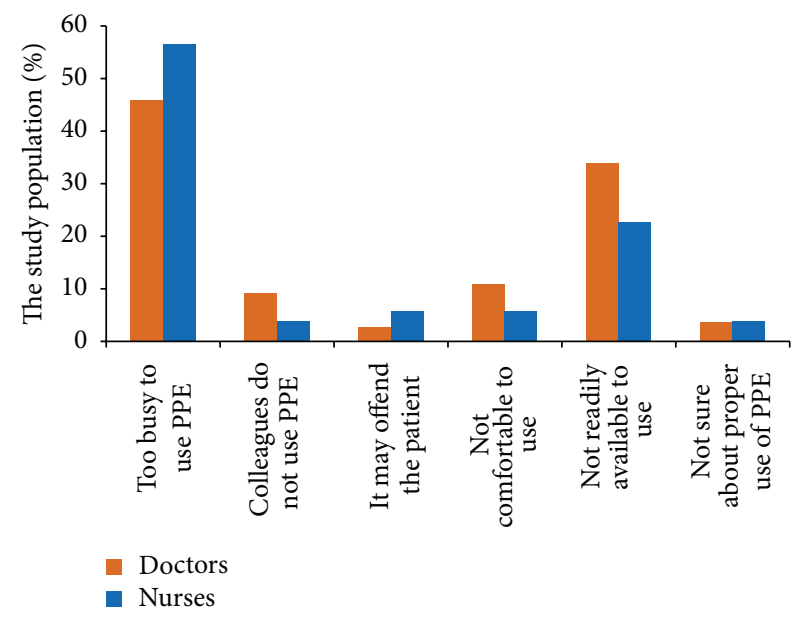

FIGURE 1: Barriers to PPE compliance among HCWs $(N=162)$.

Regarding eye protection, our study showed that only $22 \%$ reported compliance as compared to similar studies from India, where $32 \%$ of the HCWs wore eye protection when indicated $[16,17]$. Contrary to this, compliance with the use of eye protective gear was found to be $63 \%$ in developed countries [14]. Likewise, in comparison to the developed countries [14] where a whopping $62 \%$ consistently used outer protective clothing, only about $28 \%$ of the respondents in this study claimed using it when indicated.

In the current study $17.2 \%$ of the HCWs reported at least one NSI in the previous one year, whereas a higher proportion of NSIs (30-57\%) have been reported in studies from North West Ethiopia [18], Indianapolis [19], sub-Saharan countries [20], southern Ethiopia [21], and Indonesia [22]. Likewise, a study from North India [23] has also reported high proportion $(80.1 \%)$ of NSIs among the HCWs of a tertiary 
care hospital. It is of concern that of the $17.3 \%$ NSIs reported in the study only $5.6 \%$ were conveyed to the concerned hospital authorities, which is in contrast to the findings (37.8\%) from elsewhere [21]. It is also disturbing that more than half of the participants $(59.3 \%)$ did not appear to follow needle safety precautions and recapping needles was recounted as a common practice. This is almost in sync with the findings from rural North India and Nigeria where about 30-40\% of the participants resorted to recapping of needles always $[16,24]$. Studies have shown $87 \%$ to $95 \%$ compliance with the correct disposal of sharps into designated sharps containers $[14,17]$, but the reported practice in this population is slightly lower $(80 \%)$.

The study findings show the existence of inadequate needle safety precautions, low compliance with standard guidelines, and improper disposal of sharps among the health care workforce in a trauma care setting. This is despite the presence of an active infection control committee and the presence of posters stressing the need to comply with standard precautions.

There are certain inherent limitations in our study. As this report is based on self-reported cross-sectional study findings, we cannot rule out the possibility of bias resulting in an overestimation of the declared compliance. A longitudinal design could help us establish these findings with more certainty.

\section{Conclusion}

There is an urgent requirement to address the issues with reference to the barriers identified in the study. The postexposure prophylaxis policy of the health facility needs to be widely disseminated to the HCWs of the trauma triage centre for better reporting of NSIs. There is also the need to effectively put in place a hospital process that ensures ready availability of PPEs at the trauma triage centre. Besides, enhancement of the existing training on standard precautions for the trauma triage staff could reinforce the need to comply with standard guidelines however hard-pressed for time. Additionally, establishment of an effective occupational health cell incorporating all these elements including periodic surveillance could be the way forward. Future research could evaluate the efficacy of such an initiative in dealing with standard precautions and compliance.

\section{Conflict of Interests}

The authors declare that there is no conflict of interests regarding the publication of this paper.

\section{References}

[1] "Recommendations for prevention of HIV transmission in healthcare settings," http://www.cdc.gov/mmwr/mmwrsrch.htm.

[2] "Guidelines for prevention of transmission of human immunodeficiency virus and hepatitis B virus to health-care and public-safety workers: a response to P.L. 100-607. The Health Omnibus Programs Extension Act of 1988," Morbidity and Mortality Weekly Report, vol. 38, supplement 6, pp. 3-37, 1989.
[3] "Guide to Infection Prevention for Outpatient Settings: Minimum Expectations for Safe Care," http://www.cdc.gov/HAI/ pdfs/guidelines/standatds-of-ambulatory-care-7-2011.pdf.

[4] "World Health Report 2002: reducing risks, promoting healthy life," http://www.who.int/whr/previous/en/.

[5] J. L. Gerberding, "Incidence and prevalence of human immunodeficiency virus, hepatitis B virus, hepatitis $\mathrm{C}$ virus, and cytomegalovirus among health care personnel at risk for blood exposure: final report from a longitudinal study," Journal of Infectious Diseases, vol. 170, no. 6, pp. 1410-1417, 1994.

[6] R. Marcus, "The CDC cooperative needle sticks surveillance group. Surveillance of health care workers exposed to blood from patients infected with the human immunodeficiency virus," The New England Journal of Medicine, vol. 319, pp. 1118$1123,1988$.

[7] E. S. Wong, J. L. Stotka, V. M. Chinchilli, D. S. Williams, C. G. Stuart, and S. M. Markowitz, "Are universal precautions effective in reducing the number of occupational exposures among health care workers? A prospective study of physicians on a medical service," Journal of the American Medical Association, vol. 265, no. 9, pp. 1123-1128, 1991.

[8] World Health Organization, "Health care worker safety," 2014, http://www.who.int/injection_safety/toolbox/en/AM_HCW_ Safety_EN.pdf.

[9] C. Roberts, "Universal precautions: improving the knowledge of trained nurses," British Journal of Nursing, vol. 9, no. 1, pp. $43-47,2000$.

[10] M. Kermode, D. Jolley, B. Langkham, M. S. Thomas, W. Holmes, and S. M. Gifford, "Compliance with Universal/Standard Precautions among health care workers in rural north India," The American Journal of Infection Control, vol. 33, no. 1, pp. 27-33, 2005.

[11] S. Wu, L. Li, Z. Wu et al., "Universal precautions in the era of HIV/AIDS: perception of health service providers in Yunnan, China," AIDS and Behavior, vol. 12, no. 5, pp. 806-814, 2008.

[12] A. Kotwal and D. K. Taneja, "Health care workers and universal precautions: perceptions and determinants of non-compliance," Indian Journal of Community Medicine, vol. 35, no. 4, pp. 526528, 2010.

[13] O. E. Amoran and O. O. Onwube, "Infection control and practice of standard precautions among healthcare workers in northern Nigeria," Journal of Global Infectious Diseases, vol. 5, no. 4, pp. 156-163, 2013.

[14] R. R. M. Gershon, D. Vlahov, S. A. Felknor et al., "Compliance with universal precautions among health care workers at three regional hospitals," American Journal of Infection Control, vol. 23, no. 4, pp. 225-236, 1995.

[15] E. P. Simard, J. T. Miller, P. A. George et al., "Hepatitis $B$ vaccination coverage levels among healthcare workers in the United States, 2002-2003," Infection Control and Hospital Epidemiology, vol. 28, no. 7, pp. 783-790, 2007.

[16] R. Holla, T. Kanchan, N. Kumar et al., "Perception and practices of standard precautions among health care professionals at tertiary care hospitals in coastal South India," Asian Journal of Pharmaceutical and Clinical Research, vol. 7, no. 2, pp. 101-104, 2014.

[17] B. R. Sangwan, A. Kotwal, and A. K. Verma, "Occupational exposure to blood and body fluids amongst health care workers in a teaching hospital of the Armed Forces," Medical Journal Armed Forces India, vol. 67, no. 1, pp. 21-24, 2011. 
[18] D. Haile and Y. Berhane, "Injection practice in north western Ethiopia," Ethiopian Medical Journal, vol. 35, no. 2, pp. 117-125, 1997.

[19] B. N. Doebbeling, T. E. Vaughn, K. D. McCoy et al., "Percutaneous injury, blood exposure, and adherence to standard precautions: are hospital-based health care providers still at risk?” Clinical Infectious Diseases, vol. 37, no. 8, pp. 1006-1013, 2003.

[20] F. M. Nsubuga and M. S. Jaakkola, "Needle stick injuries among nurses in sub-Saharan Africa," Tropical Medicine and International Health, vol. 10, no. 8, pp. 773-781, 2005.

[21] M. Tadesse and T. Tadesse, "Epidemiology of needlestick injuries among health-care workers in Awassa City, Southern Ethiopia," Tropical Doctor, vol. 40, no. 2, pp. 111-113, 2010.

[22] Y. I. S. Sari, K. Ibrahim, H. Haroen et al., "Knowledge, attitude and perceived adherence with universal precautions among health care workers in the obstetrics and gynaecology department of an Indonesian teaching hospital," International Journal of Infection Control, vol. 7, no. 4, 2014.

[23] S. Muralidhar, P. K. Singh, R. K. Jain, M. Malhotra, and M. Bala, "Needle stick injuries among health care workers in a tertiary care hospital of India," Indian Journal of Medical Research, vol. 131, no. 3, pp. 405-410, 2010.

[24] W. E. Sadoh, A. O. Fawole, A. E. Sadoh, A. O. Oladimeji, and O. S. Sotiloye, "Practice of universal precautions among healthcare workers," Journal of the National Medical Association, vol. 98, no. 5, pp. 722-724, 2006. 


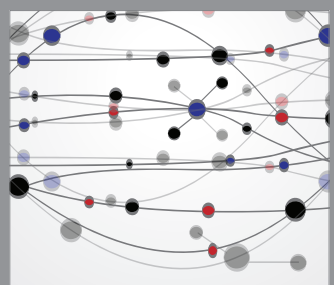

The Scientific World Journal
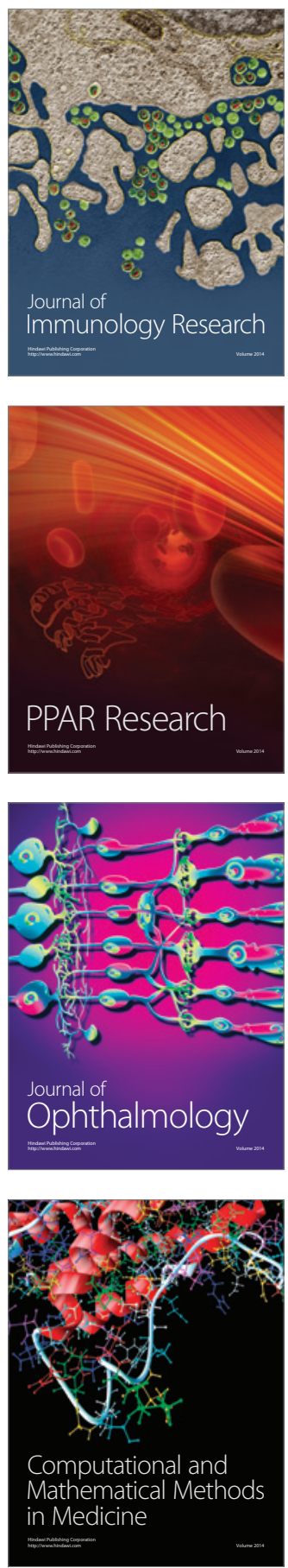

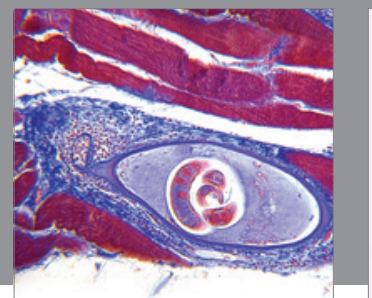

Gastroenterology

Research and Practice
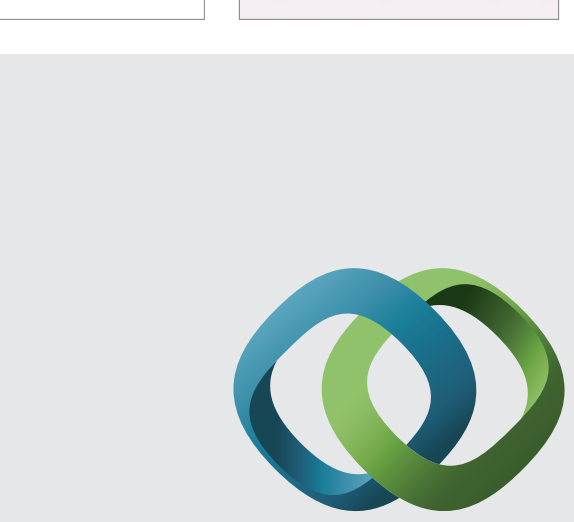

\section{Hindawi}

Submit your manuscripts at

http://www.hindawi.com
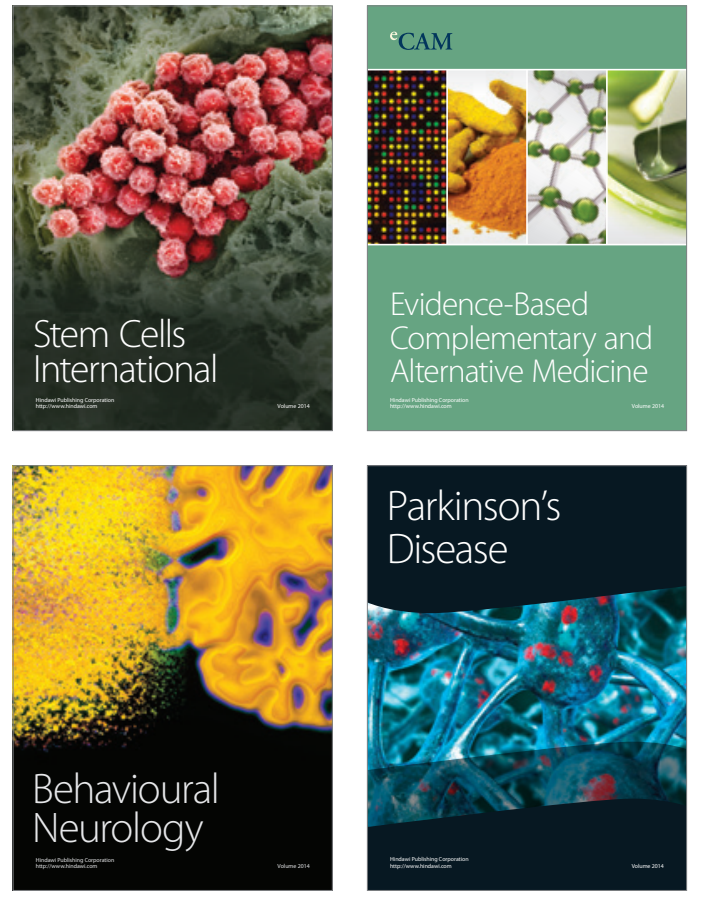
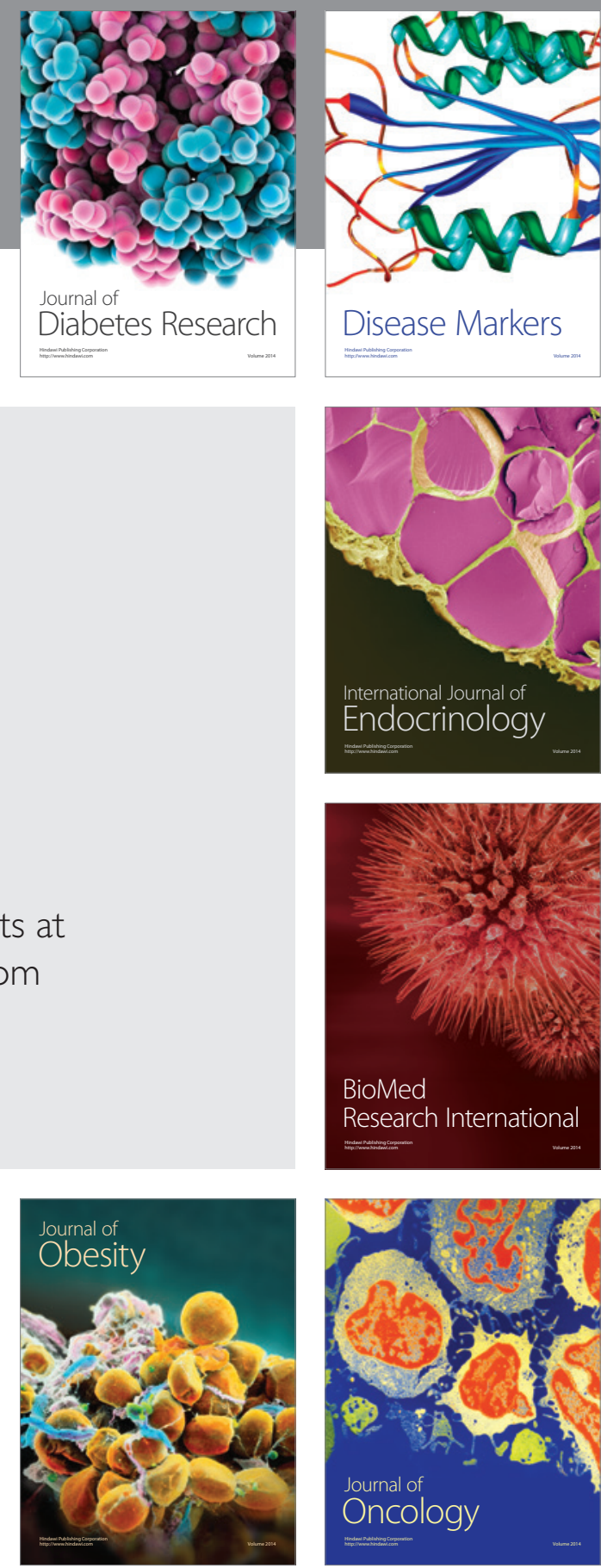

Disease Markers
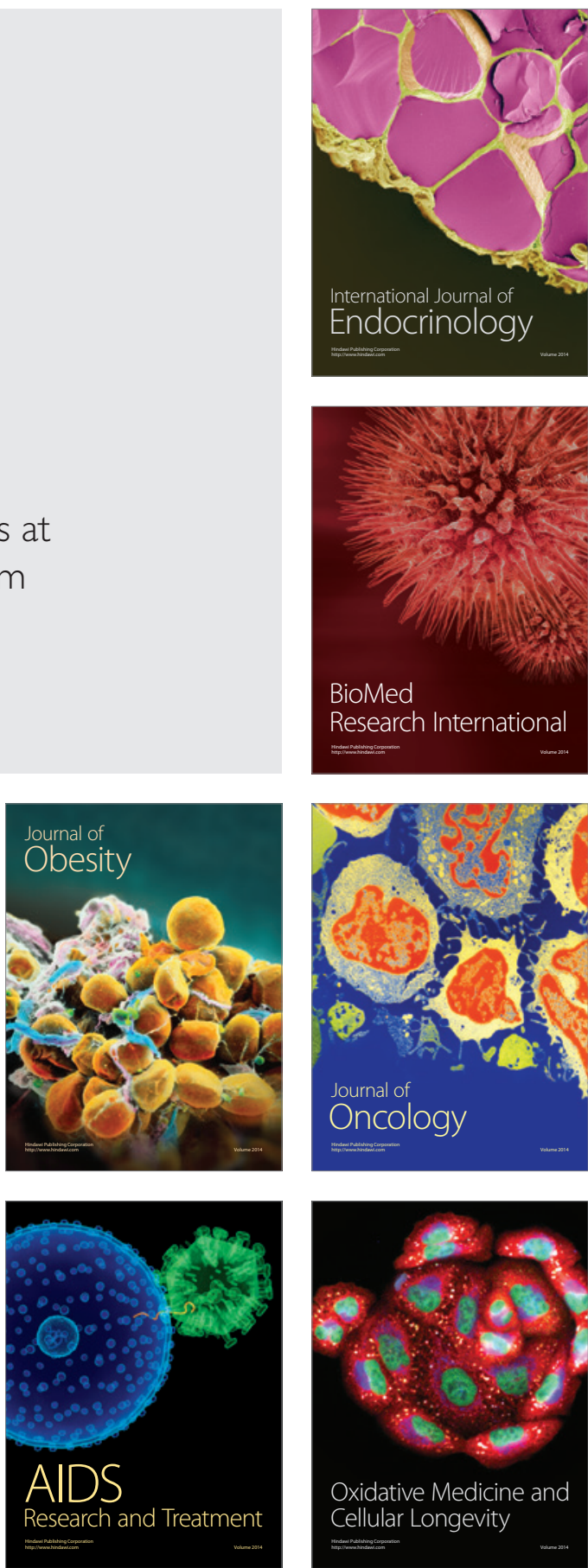